\title{
FACTORS ASSOCIATED WITH THE DISTRIBUTIONS OF ORCHIDS IN THE JESENÍKY MOUNTAINS, CZECH REPUBLIC
}

\author{
ZUZANA ŠTÍPKOVÁ1,2,*, DUŠAN ROMPORTL ${ }^{1,3}$, \\ VERONIKA ČERNOCKÁ ${ }^{2}$, and PAVEL KINDLMANN ${ }^{1,2}$ \\ ${ }^{1}$ Global Change Research Institute, Czech Academy of Science, Bělidla 986/4a, 60300 Brno, Czech Republic \\ 2 Institute for Environmental Studies, Faculty of Science, Charles University, Benátská 2, 12801 Prague 2, Czech Republic \\ ${ }^{3}$ Department of Physical Geography and Geoecology, Faculty of Science, Charles University, Albertov 6, 12843 Praha 2, \\ Czech Republic \\ *Corresponding author: zaza.zuza@seznam.cz
}

\section{ABSTRACT}

\begin{abstract}
Species distribution models are a useful tool and are now often used in many branches of biology, especially when dealing with threatened organisms. In combination with GIS techniques, these models are especially important and valuable for predicting the occurrence of rare species, for example orchids. Orchids are an endangered plant group, protected worldwide. Questions about their conservation are therefore highly discussed, but not all factors affecting their survival and distribution are known. Here we present an example of using SDMs for analysing orchid species occurrence data from the Jeseníky Mountains in the Czech Republic. Our data were analysed using the MaxEnt program, which produces species distribution maps and thus allows the prediction of the potential occurrence of orchids at yet unknown localities. This program also determines the environmental factors affecting species distribution. This is important for the better protection of orchids, because only by knowing these factors can new localities be found or the management plans that are crucial for maintaining orchid localities be improved. We studied the most abundant orchid species in the given region. We determined the most important factors affecting their occurrence and also areas, where new sites are most likely to be discovered and depicted them in potential distribution maps. This approach can help in finding new localities of orchids and in understanding, which environmental factors influence the occurrence of endangered orchids.
\end{abstract}

Keywords: orchids, climatic factors, environmental factors, Maxent, species distribution models

\section{Introduction}

Recently, questions concerning species diversity have become more and more important for scientists worldwide because the diversity of life on Earth is in rapid decline (Dirzo and Raven 2003; Possingham and Wilson 2005). Thus, understanding the main factors determining species diversity (Possingham and Wilson 2005) and identifying important areas for conservation (Tsiftsis et al. 2011) is important because this is crucial for their survival. This especially holds for threatened groups such as orchids (Efimov 2011; Feldman and Prat 2011).

The orchid family is one of the largest and most diverse in taxa in the flowering plant kingdom, with estimates of 880 genera and about 20,000 to 35,000 species (Dressler 1993; Chase et al. 2003; Cribb et al. 2003; Tsiftsis et al. 2011). Many characteristics, such as great species richness, their specific role in ecosystems or endangered situations make it crucial to explore the distribution and conservation status of Orchidaceae (Zhang et al. 2015).

Predictive modelling of the geographic distributions of species based on the environmental conditions at sites of known occurrence is an important technique in analytical biology, with applications in conservation and reserve planning, ecology, evolution, epidemiology, invasive-species management and other fields (Yom-Tov and Kadmon 1998; Corsi et al. 1999; Peterson et al. 1999; Scott et al. 2002; Welk et al. 2002; Peterson and Shaw
2003; Phillips et al. 2006). Species distribution models (SDMs) are widely used in many branches of biology (Elith and Leathwick 2009) and are especially useful for threatened species (Guisan et al. 2013). These numerical tools combine species occurrence records with environmental data (Elith and Leathwick 2009). In combination with GIS techniques, these models are especially important and useful for predicting occurrence of rare species (Guisan and Thuiller 2005), like endangered species of Orchidaceae.

In this study, we used the maximum entropy algorithm in the MaxEnt application (Elith et al. 2006; Phillips et al. 2006; Phillips and Dudík 2008; Elith et al. 2011). This algorithm uses maximum entropy and Bayesian methods to estimate the probability distribution for each species based on their presence or absence. Since becoming available in 2004, MaxEnt has been utilized extensively for modelling species distributions. This approach is used by conservationists for predicting the distribution of a species from a set of occurrence records and environmental variables (Elith et al. 2011; Fourcade et al. 2014) as well as many other fields of biology and ecology that cover diverse aims across ecological, evolutionary, conservation and biosecurity applications (Elith et al. 2011). Presence-only modelling methods require a set of known species occurrences together with predictor variables such as topographic, climatic, edaphic, biogeographic and/or remotely sensed data (Phillips et al. 2006; Phillips 
and Dudík 2008). An output of the MaxEnt program are maps of the distribution of suitable niches and information on the input variables needed to be put into the model.

As previously stated, species distribution data and modelling are increasingly being used. Although the relationship between species distribution and environmental variables has been extensively investigated (Peppler-Lisbach and Schröder 2004; Ferrier and Guisan 2006; Ferrier et al. 2009), these relationships were rarely used in the past to explain the spatial arrangement of high conservation value areas (Gelfand et al. 2005). Despite the long history of studies on orchids, only a minute part of previous papers concerning potential and spatial distribution, niche conservatism, phytogeography, migration routes or conservation strategies of this taxonomic group included the use of species distribution models (e.g. Tsiftsis et al. 2011; Angulo et al. 2012; Kolanowska 2013; Wan et al. 2014; Vogt-Schilb et al. 2015; Hernandez-Ruiz et al. 2016; Reina-Rodríguez et al. 2016; Vollering et al. 2016).

All recently published studies on orchids use only climatic variables in the modelling of species' distributions. Here both climatic variables and the effect of vegetation cover (mainly consolidated layer of ecosystem, KVES) are seen as determining the distribution of species of orchids in the Czech Republic. These two factors have not been previously seen as acting together in determining the distribution of orchids.

\section{Methods}

The study site was located in the mountain range in the Hrubý and Nízký Jeseník Nature Conservation Area, in the Highlands of Hanušovice and surroundings in the
Czech Republic (Fig. 1). This area is situated in the northeast of the Jeseníky Nature Conservation Area (NCA) at altitudes from about 300 to 1400 masl. Because of the wide range in altitude, many different types of habitats occur in this region, such as peat bogs, meadows and pastures, oak-hornbeam forests or are naturally forest-free areas. Many of the different habitats in the Jeseníky NCA are managed and suitable for many species of orchids, even critically endangered species such as Listera cordata or Orchis mascula.

As a source of data we used information in 5 databases: those of the Nature Conservation Agency of the Czech Republic (2006), the Czech National Phytosociological Database and the Floristic Documentation, all deposited in the Department of Botany and Zoology, Faculty of Science of the Masaryk University in Brno (2005), the database of the South Bohemian Branch of the Czech Botanical Society (2017) and that of the inheritance of the late František Procházka (10,000 items, digitized from original cards). All the data from these databases are deposited in one comprehensive database at the Global Change Research Institute CAS, Department of Biodiversity Research in České Budějovice, but in order to protect the orchids at the localities studied, there is no public access to either of these databases.

During 2017, we visited as many localities as possible to check whether particular species of orchids were still present there. If the species was found, the number of flowering plants was counted and all important information, such as accurate GPS coordinates, the state of the locality and whether it was mown were recorded. A total of 146 localities was checked.

Because of the special demands we used the methods in MaxEnt and only the four most numerous species

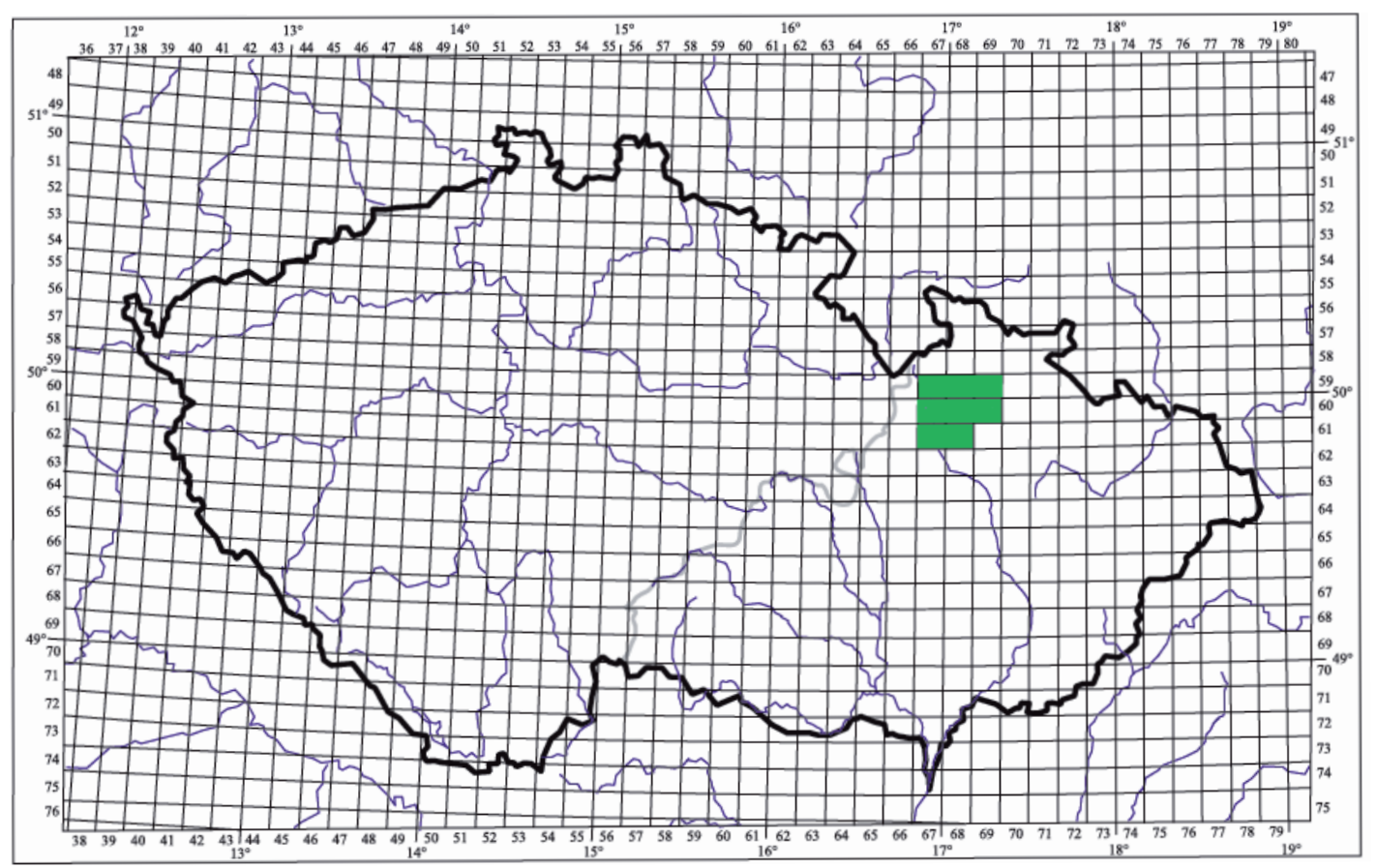

Fig. 1 Map showing the location of the study site, depicted in green, in the Czech Republic - Jeseníky Nature Conservation Area. 
were incorporated in all analyses. The first species analysed was Dactylorhiza fuchsii (Druce) Soó, which occurs in wet as well as in dry meadows, the second was Dactylorhiza majalis (Rchb.) P. F. Hunt \& Summerh., which lives in wet meadows, the third was Gymnadenia conopsea (L.) R. Brown, which usually occurs in xerothermic meadows or pastures and the fourth was Platanthera bifolia Rich., which flourishes in open deciduous forests.

A set of environmental and habitat variables was obtained from datasets for the Czech Republic. The list of all variables used in the analysis of the four most numerous species is described in Table 1.

All analyses were done using the MaxEnt program version 3.3.2 (Phillips et al. 2006; Phillips and Dudík 2008; Elith et al. 2011). In this program, the jack knife procedure reveals how the species react to different environmental factors. Two different blue bars are always displayed in the resulting figure. The length of the darkblue bar indicates the importance of the effect of the selected factor. The length of the light-blue bar indicates how much information would be lost, if the corresponding factor were excluded from the analysis. Thus, deletion from the model of a factor associated with a long lightblue bar would result in a large loss of explanatory power. Then we performed the analysis for each species.

Before describing them, we have to elucidate the meaning of one factor used in the analyses that consists of 40 sub-factors: the "consolidated layer of ecosystems" (KVES) (AOPK ČR 2013). KVES is a list of 40 types of habitat, named KVES_1, KVES_2, ..., KVES_40. For example, KVES_6 is mesophilic meadow, KVES_29 is deciduous forest etc. (see Table 2 for further examples). Based on our many years research on orchids and information in the literature on ecological requirements of individual orchid species (Procházka and Velísek 1983; Dykyjová 2003; Jersáková and Kindlmann 2004; Průša 2005), we thought that these factors might be important determinants of the occurrence of these species and therefore included them in the analyses. KVES without a number is the presence of a certain class of habitat, which is therefore a categorical variable. If this is statistically significant, it means that the occurrence of the corresponding species of orchid depends on a particular habitat. Sometimes, environmental heterogeneity (here called KVES_var - see Table 2), expressed as the number of different types of KVES per unit area (sometimes also called "grain size" in the literature, especially that on landscape ecology) may be important, a large KVES_var indicates that the landscape consists of a mosaic of many small units, like fields, pastures, meadows, forests etc., which usually indicates a low intensity of agriculture and consequently a good habitat for protected species. Therefore, we always included KVES_var in our analysis.

In the analysis, the influence of climatic factors, environmental variables and other basic abiotic factors on orchid distribution was studied. There is a list of these factors in Table 1 and their description in Table 2. The
Table 1 The list of variables used in the analysis.

\begin{tabular}{|l|l|l|l|}
\hline $\begin{array}{c}\text { Dactylorhiza } \\
\text { fuchsii }\end{array}$ & $\begin{array}{c}\text { Dactylorhiza } \\
\text { majalis }\end{array}$ & $\begin{array}{c}\text { Gymnadenia } \\
\text { conopsea }\end{array}$ & $\begin{array}{c}\text { Platanthera } \\
\text { bifolia }\end{array}$ \\
\hline alkali & dem & dem & dem \\
\hline dem & frost_days & KVES & KVES \\
\hline frost_days & KVES & KVES_6 & KVES_6 \\
\hline KVES & KVES_6 & KVES_var & KVES_29 \\
\hline KVES_6 & KVES_9 & reactivity & KVES_var \\
\hline KVES_9 & KVES_20 & solar_rad & reactivity \\
\hline KVES_20 & KVES_23 & temp & solar_rad \\
\hline KVES_23 & KVES_var & TPI & TPI \\
\hline KVES_var & reactivity & vert_het & vert_het \\
\hline reactivity & solar_rad & & \\
\hline temp & temp & & \\
\hline TPI & TPI & & \\
\hline vert_het & vert_het & & \\
\hline
\end{tabular}

Table 2 Description of all important factors used in all analyses.

\begin{tabular}{|l|l|}
\hline \multicolumn{1}{|c|}{ Code } & \multicolumn{1}{c|}{ Description } \\
\hline alkali & alkalinity of bedrock \\
\hline dem & altitude \\
\hline frost_days & number of freezing days per year \\
\hline KVES & consolidated layer of ecosystems \\
-4 & - alluvial and wet meadows \\
-6 & - mesophilic meadows \\
-7 & - alpine meadows \\
-9 & - floodplain and wetland forests \\
-11 & - brash forests \\
-19 & - wetlands and coastal vegetation \\
-20 & - peat bogs and water springs \\
-23 & - swamps and marshes \\
-29 & - deciduous forests \\
-30 & - mixed forests \\
- var & - habitat heterogeneity (number of different types of \\
& habitats) \\
\hline reactivity & reactivity of rocks in a bedrock \\
\hline solar_rad & $\begin{array}{l}\text { solar radiation } \text { - total amount of incoming solar insola- } \\
\text { tion (WH/m }{ }^{2} \text { ) }\end{array}$ \\
\hline temp & temperature \\
\hline TPI & topographic position index \\
\hline vert_het & $\begin{array}{l}\text { vertical heterogeneity (standard deviation in terms of } \\
\text { altitude) }\end{array}$ \\
\hline
\end{tabular}

climatic data were obtained from the Global Change Research Institute CAS and a climate character for the timeline of 1981-2011 was created. The objective of this analysis was to determine the extent to which these variables are associated with the occurrence of the species of orchid studied. However, at least some of the other most important environmental non-climatic factors were also included, so as not to produce a purely climatic model, which does not seem to be appropriate in our case, as our experience and information in the literature indicates that climate alone cannot account for the presence of orchids in these temperate and rather flat regions (Procházka and Velísek 1983; Dykyjová 2003; Jersáková and Kindl- 
Table 3 Percentage contribution of particular factors for each of the species studied.

\begin{tabular}{|c|c|c|c|c|c|c|c|}
\hline Factor & $\begin{array}{c}\text { Percentage } \\
\text { contribution } \\
\text { Dactylorhiza } \\
\text { fuchsii }\end{array}$ & Factor & $\begin{array}{c}\text { Percentage } \\
\text { contribution } \\
\text { Dactylorhiza } \\
\text { majalis }\end{array}$ & Factor & $\begin{array}{l}\text { Percentage } \\
\text { contribution } \\
\text { Gymnadenia } \\
\text { conopsea }\end{array}$ & Factor & $\begin{array}{c}\text { Percentage } \\
\text { contribution } \\
\text { Platanthera } \\
\text { bifolia }\end{array}$ \\
\hline frost_days & 35 & reactivity & 20.5 & dem & 47.8 & solar_rad & 27.1 \\
\hline reactivity & 17 & KVES_9 & 19 & KVES & 21.5 & KVES & 25.7 \\
\hline KVES_20 & 8.9 & KVES_6 & 14.4 & KVES_var & 11.7 & KVES_var & 21.6 \\
\hline KVES_9 & 8.8 & dem & 13.8 & KVES_6 & 9.7 & reactivity & 11.4 \\
\hline KVES_var & 6.6 & KVES & 12.8 & reactivity & 4.3 & KVES_6 & 5.9 \\
\hline KVES & 6.5 & KVES_var & 10.4 & vert_het & 1.8 & dem & 4.6 \\
\hline alcali & 6.2 & vert_het & 3.8 & saolr_rad & 1.7 & vert_het & 2.3 \\
\hline TPI & 3.2 & KVES_20 & 2.3 & TPI & 1.2 & KVES_29 & 1.5 \\
\hline KVES_6 & 2.5 & frost_days & 1.3 & temp & 0.3 & TPI & 0.1 \\
\hline dem & 2.3 & salor_rad & 1.2 & & & & \\
\hline vert_het & 1.5 & TPI & 0.5 & & & & \\
\hline temp & 1.3 & temp & 0.1 & & & & \\
\hline KVES_23 & 0.1 & KVES_23 & 0 & & & & \\
\hline
\end{tabular}

mann 2004; Průša 2005). Therefore, we selected factors based on our experience and information in the orchid literature, such as descriptions of the ecological requirements of the species of orchids studied (Procházka and Velísek 1983; Dykyjová 2003; Jersáková and Kindlmann 2004; Průša 2005). We also added TPI (topographic position index) and vertical heterogeneity (vert_het; see Table 1) as they might be important for the occurrence of particular species of orchids. TPI classifies landscape in terms of slope, landform category and its position in the terrain, for example, whether at the top of a hill, in a valley or near a depression. Another important environmental variable is vertical heterogeneity (vert_het). This factor indicates the degree to which the landscape undulates near the locality studied, in terms of altitudinal range. All of these factors are described in Table 2. The influence of alkalinity and type of rock at a particular locality were also included in the analysis (Chuman et al. 2017) because according to the literature, some orchids only grow in soils on one or two types of rock (Procházka and Velísek 1983; Dykyjová 2003; Průša 2005). The final potential distribution map was then created.

In our results, only the most important factors for each species of orchid are described.

The list of factors used in the analysis is given in Table 1 and detailed descriptions of each factor in Table 2.

\section{Results and Discussion}

\section{Dactylorhiza fuchsii (Druce) Soó}

The results of the jack knife procedure illustrated in Fig. 2 indicate that many of the variables included in the analysis have an effect on the distribution of $D$. fuchsii. According to the Maxent analysis, the most important factors are the number of frost days per year (frost_days;
$35 \%)$ and reactivity of the bedrocks at a particular locality (reactivity; $17 \%$ ). Other variables had only a small effect (less than $10 \%$ of variability explained) and thus were not included in the following description. A detailed list of the contributions (\%) of particular factors for each of the species studied is shown in Table 3 .

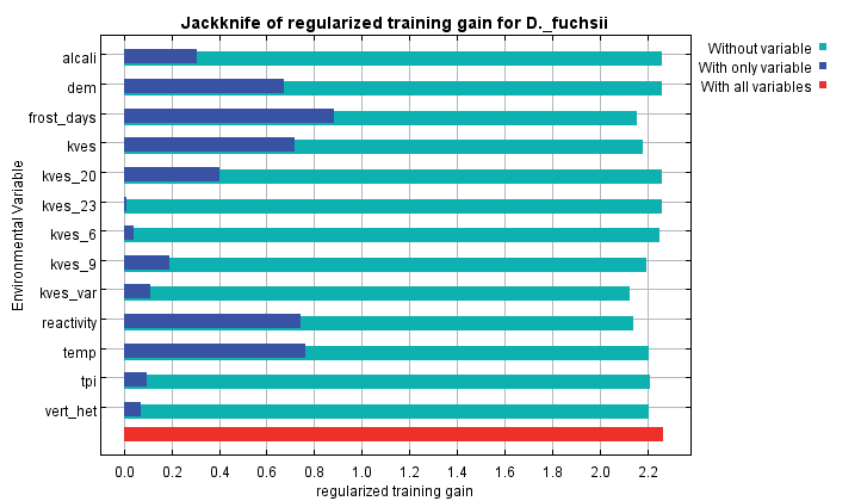

Fig. 2 The graph of the results of the jack knife procedure of selected factors for Dactylorhiza fuchsii.

A closer look at the associations of the most important variables with the distribution of this species (Fig. 3) reveals certain patterns.

Fig. 3a indicates that $D$. fuchsii has a high probability of being present in areas with more frost days per year. From this picture, it is clearly visible that this species is almost absent in areas where there are only a few frost days per year. This means that $D$. fuchsii should occur at high altitudes where the temperatures are much colder than in the lowlands, which is in agreement with information in the literature (see Procházka and Velísek 1983; Průša 2005).

In Fig. 3b, the association with the reactivity of the bedrock at a particular locality is shown. According to this, D. fuchsii should occur with high probabili- 

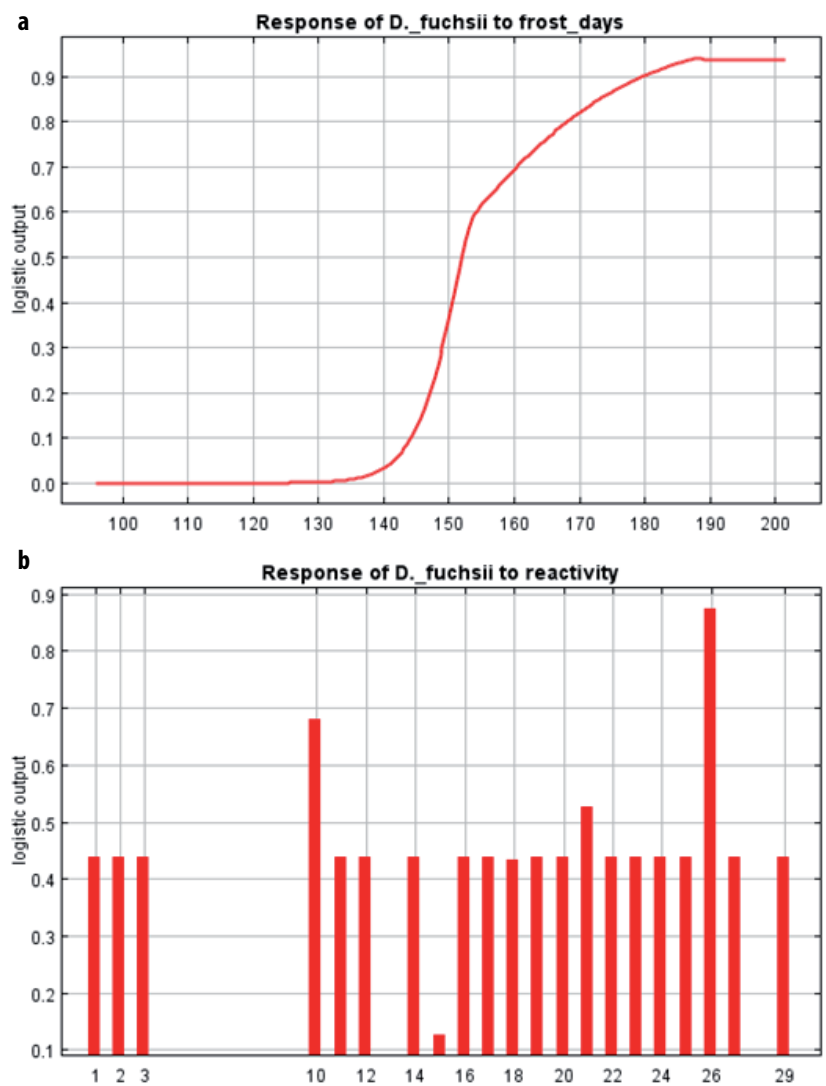

Fig. 3 Association of Dactylorhiza fuchsii with a) number of frost days per year (frost_days) and b) reactivity of bedrock at a particular locality (reactivity).

ty on sandstone, conglomerates or arkose (number 26) and metamorphic rocks like phyllite (number 10) and low probability on consolidated sediment rocks like greywacke, siltstone or shale (number 15).

In Fig. 4, is a map showing the potential distribution of $D$. fuchsii. It is clear that there are still some places in the region studied that are also suitable for this species but all of them are in the vicinity of its current distribution. The most suitable places for finding new localities are mainly around Skřítek National Nature Reserve and west of the village Karlov pod Pradědem in the highest parts of the Jeseníky mountains.

\section{Dactylorhiza majalis (Rchb.) P. F. Hunt \& Summerh.}

The results of the jack knife procedure illustrated in Fig. 5 indicates the various factors associated with the distribution of D. majalis. Many of the selected variables have an effect but according to the analysis, the most important factors are the reactivity of the bedrock at a particular locality (reactivity; 20.5\%), presence of floodplain and wetland forests (KVES_9; 19\%) and mesophilic meadows (KVES_6; 14.4\%) nearby. We did not include consolidated layer of ecosystems (KVES) and altitude as important even though they appear to be important, because as stated above, KVES without a number means that the occurrence of a particular species of orchid is habitat dependent. The jack knife

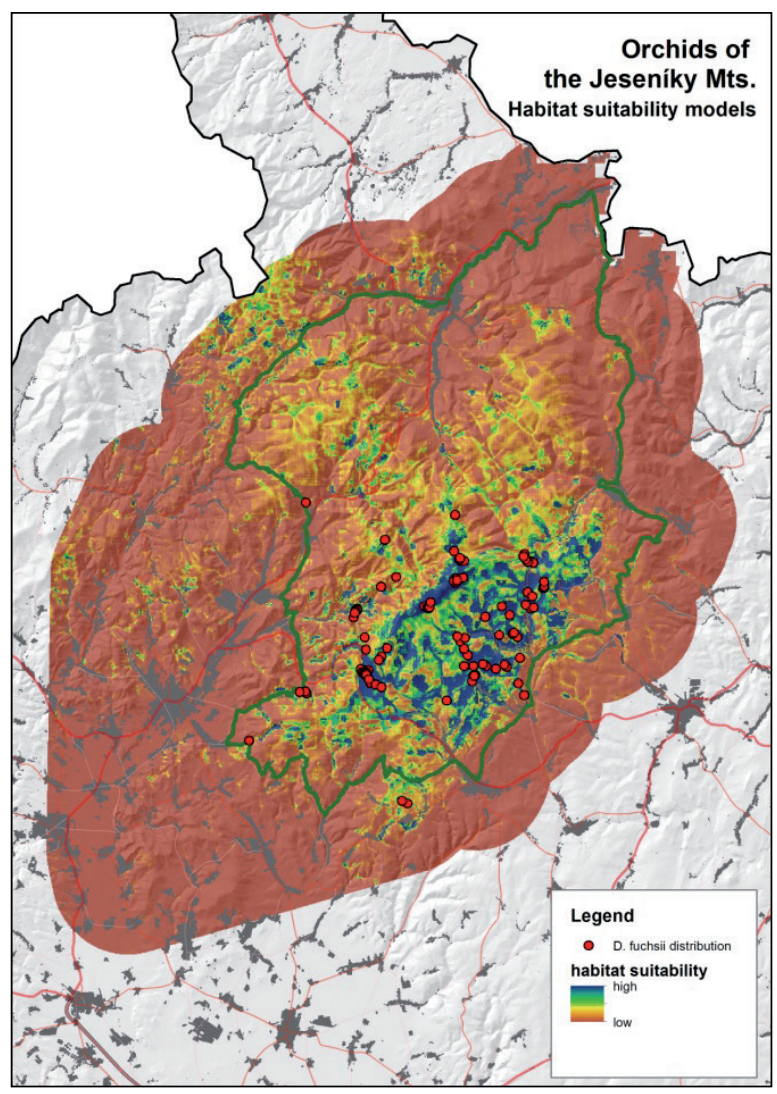

Fig. 4 Map of the potential distribution of Dactyorhiza fuchsii in the Jeseníky Mountains. The green line on the map is the border of the Jeseníky Nature Conservation Area.

procedure revealed certain types of KVES (KVES_6 and 9) as more important, thus they were not included as a separate factor again. In the case of altitude (dem), the analysis indicates $700 \mathrm{~m}$ as the most probable altitude for the occurrence of $D$. majalis, but the distribution of this species extends from lowlands to mountains (Procházka and Velísek 1983; Dykyjová 2003; Jersáková and Kindlmann 2004; Průša 2005). The indicated altitude $(700 \mathrm{~m})$ is due to the mean altitude of the area studied in the Jeseníky Mountains, thus this factor was also not included as an important variable (see Table 3 for more information).

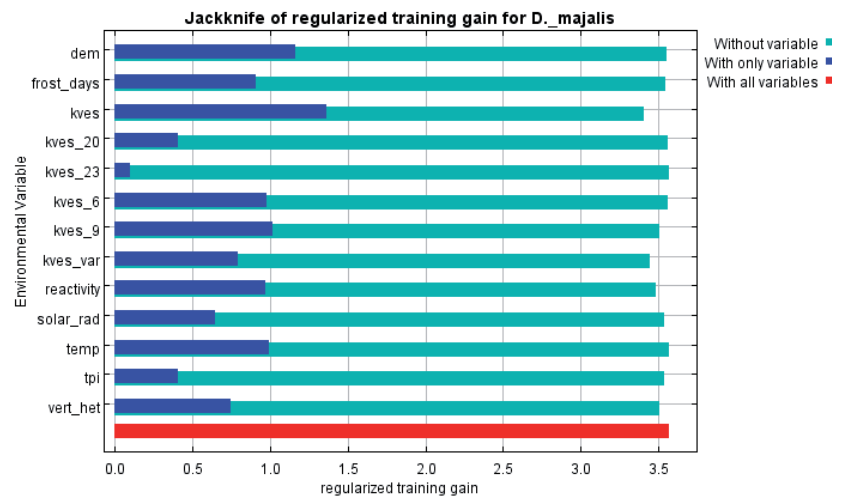

Fig. 5 The graph of the results of the jack knife procedure of selected factors for Dactylorhiza majalis. 

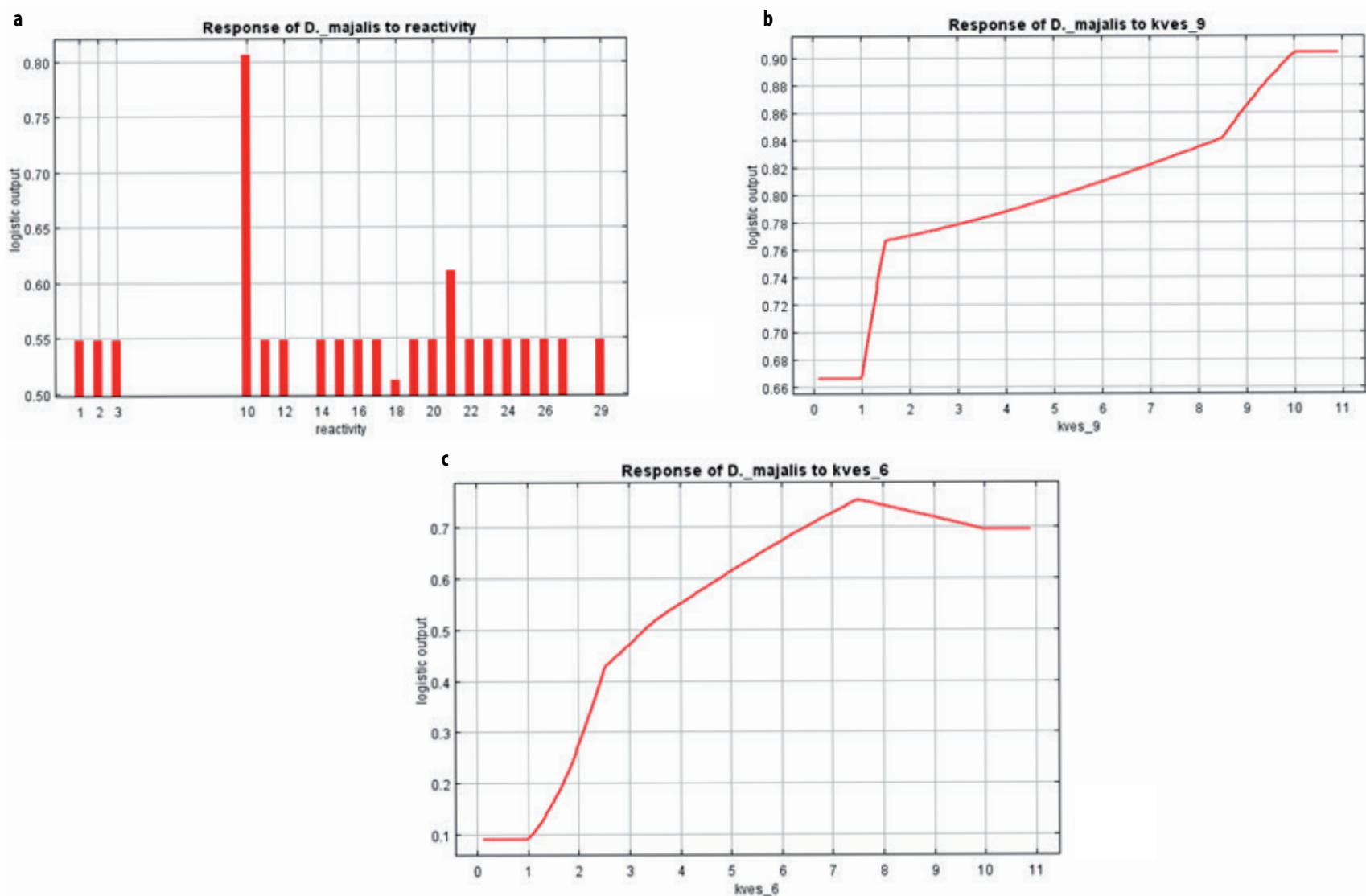

Fig. 6 Association of Dactylorhiza majalis with the a) reactivity of the bedrock at a particular locality (reactivity), b) presence of floodplain and wetland forests near selected localities (KVES_9) and c) presence of mesophilic meadows near selected localities (KVES_6).

A closer inspection of the factors that were significantly associated with the distribution of D. majalis (Fig. 6) proved interesting.

Fig. 6a indicates the association of this species with the reactivity of the bedrock (reactivity). It occurs mainly in areas with rock types 10 and 21, which are metamorphic rocks like phyllite (No. 10) or metagabbro and dolerite (No. 21). This species does not flourish on metagranite, migmatite or metagreywacke (No. 18).

Fig. $6 \mathrm{~b}$ clearly shows that the higher probability of occurrence of $D$. majalis is in areas with high occurrence of floodplain and wetland forests (KVES_9). Although D. majalis is mainly a meadow species (Jersáková and Kindlmann 2004; Průša 2005), it is also possible to find it in small open patches in open forests (e.g. forest and grassy clearings or small wet meadows).

Fig. $6 \mathrm{c}$ indicates the association of the distribution of this species with mesophilic meadows (KVES_6). It is clear that the occurrence of this species is closely associated with mesophilic meadows. This means that $D$. majalis is more likely to occur in areas in the vicinity of mesophilic meadows. Both previous figures of KVES indicate that if there are any wet areas nearby, the probability of $D$. majalis being present is almost zero. This is in accordance with the literature, which indicates that these types of habitat are suitable for this species (Procházka and Velísek 1983; Dykyjová 2003; Jersáková and Kindlmann 2004; Průša 2005).
Map of the potential distribution of D. majalis (Fig. 7) indicates there are other potentially suitable localities for this species in the Jeseníky Mountains, but most are near to existing localities. New localities are most likely to be found around Vysoká Hole hill and in the Skřítek National Nature Reserve. Other potentially suitable areas are between the villages of Karlova Studánka and Andèlská Hora and in the vicinity of the village Nová Rudná.

\section{Gymnadenia conopsea (L.) R. Brown}

The results of the jack knife procedure are illustrated in Fig. 8, which indicates that distribution of this species is associated with many of the variables considered. The analysis indicates that the most important variables are altitude (dem; 47.8\%), consolidated layer of ecosystems (KVES; $21.5 \%$ ) and habitat heterogeneity (KVES_var; $11.7 \%)$. In this case, it is relevant to mention also the fourth most important factor because it is connected with the KVES variable, which indicates that the occurrence of $G$. conopsea is dependent on a particular type of habitat, mesophilic meadows (KVES_6), which is congruent with information in the literature (Procházka and Velísek 1983; Dykyjová 2003; Jersáková and Kindlmann 2004; Průša 2005). Although this factor explained less than $10 \%$ of the variability and was not included in the list of the most important factors, it is important to mention it. The detailed contribution of each factor is shown in Table 3. 


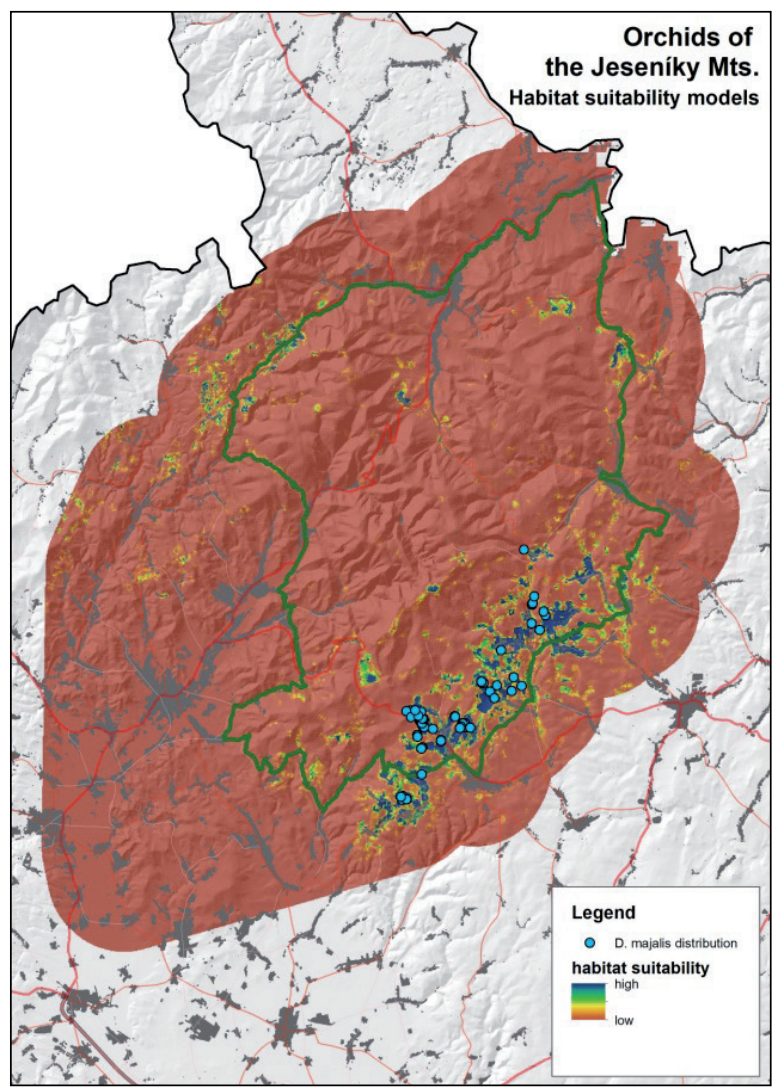

Fig. 7 Map showing the potential distribution of Dactyorhiza majalis in the Jeseníky Mountains. The green line indicates the borders of the Jeseníky Nature Conservation Area.

A closer inspection of the most important variables associated with the distribution of G. conopsea (Fig. 9) proved interesting.

Fig. 9a indicates the important association between altitude (dem) and the distribution of this species. It is clear that $G$. conopsea occurs mainly at high altitudes in highlands and mountains, and rarely in lowlands. Průša (2005) mentions that this species is absent in lowlands.

Fig. $9 \mathrm{~b}$ indicates that the distribution of this species is associated with the consolidated layer of ecosystems (KVES) and this species occurs mainly in wetlands of various types (KVES_19, KVES_6 and KVES_4), natural shrub land (KVES_17) and alpine meadows (KVES_7). Especially its possible occurrence in alpine meadows is interesting because this habitat only occurs on the highest parts of mountains in the Czech Republic and one of the areas is in the area studied, the Jeseníky Mountains. All of these results are in accordance with information in the literature (Procházka and Velísek 1983; Dykyjová 2003; Jersáková and Kindlmann 2004; Průša 2005), which indicate that this species mainly occurs in from hilly areas to mountains and in wet meadows as well as in xerothermic pastures and shrub land.

Fig. 9c indicates that the third most important factor is habitat heterogeneity (KVES_var). This indicates that the distribution of $G$. conopsea is mainly associated with landscapes consisting of a mosaic of many smaller

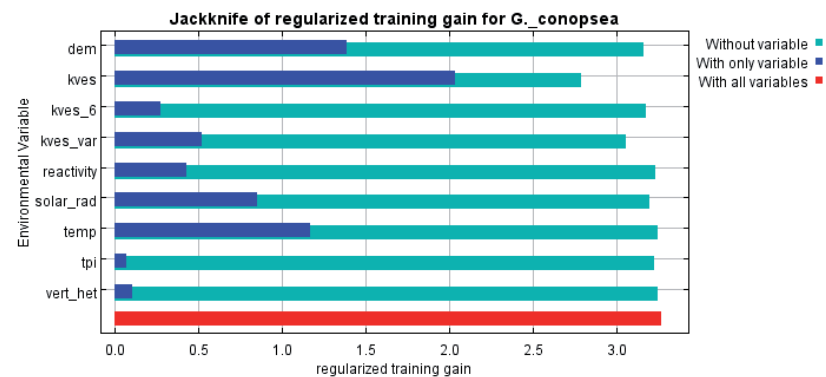

Fig. 8 The graph of the results of jack knife procedure of selected factors for Gymnadenia conopsea.

biotopes. This confirms our expectation and experience gained from field studies that this species is more likely be found in these types of landscapes, probably because they are little affected by agriculture.

In Fig. 10, there is a map of the potential distribution of G. conopsea in the area of the Jeseníky Mountains studied. It is clear that there is still a possibility of finding new localities for this orchid. Except for the current localities, the most suitable habitats are likely to be mainly on the highest mountains (e.g. Vysoká Hole, Praděd, Mravenečník) and in small areas east of the city of Jeseníky and north of village Branná outside of the Jeseníky NCA.

\section{Platanthera bifolia Rich.}

The results of the jack knife procedure are displayed in Fig. 11. The analysis revealed that solar radiation (solar_rad; $27.1 \%$ ) is the most important factor associated with the distribution of Platanthera bifolia. Other important factors are consolidated layer of ecosystems (KVES; $25.7 \%$ ) and habitat heterogeneity (KVES_var; 21.6\%). For more information about the association with various factors see Table 3 .

Closer inspection of the factors most significantly associated with the distribution of P. bifolia (Fig. 12) proved interesting.

Fig. 12a indicates that the occurrence of this species is most closely associated with solar radiation (solar_rad). In the Czech Republic, the extent of solar radiation dose not differ across the whole country so this factor mainly tells us, that $P$. bifolia occurs in shady or sunny places. From this picture, it is clear that this species occurs mainly in places with a low value for solar radiation that is in shady places. As mentioned above, this result corresponds with the information in the literature on the habitat of P. bifolia (Procházka and Velísek 1983; Dykyjová 2003; Jersáková and Kindlmann 2004; Průša 2005).

Fig. 12b indicates the biotope (KVES) most closely associated with each species. According to this analysis it is mainly brash forest (KVES_11), but also alluvial and wet meadows (KVES_4), mesophilic meadows (KVES_6), floodplain and wetland forests (KVES_9) and mixed forests (KVES_30). These results are congruent with the previous results for solar radiation that indicate this species occurs mainly in shady places. Forests are shady 

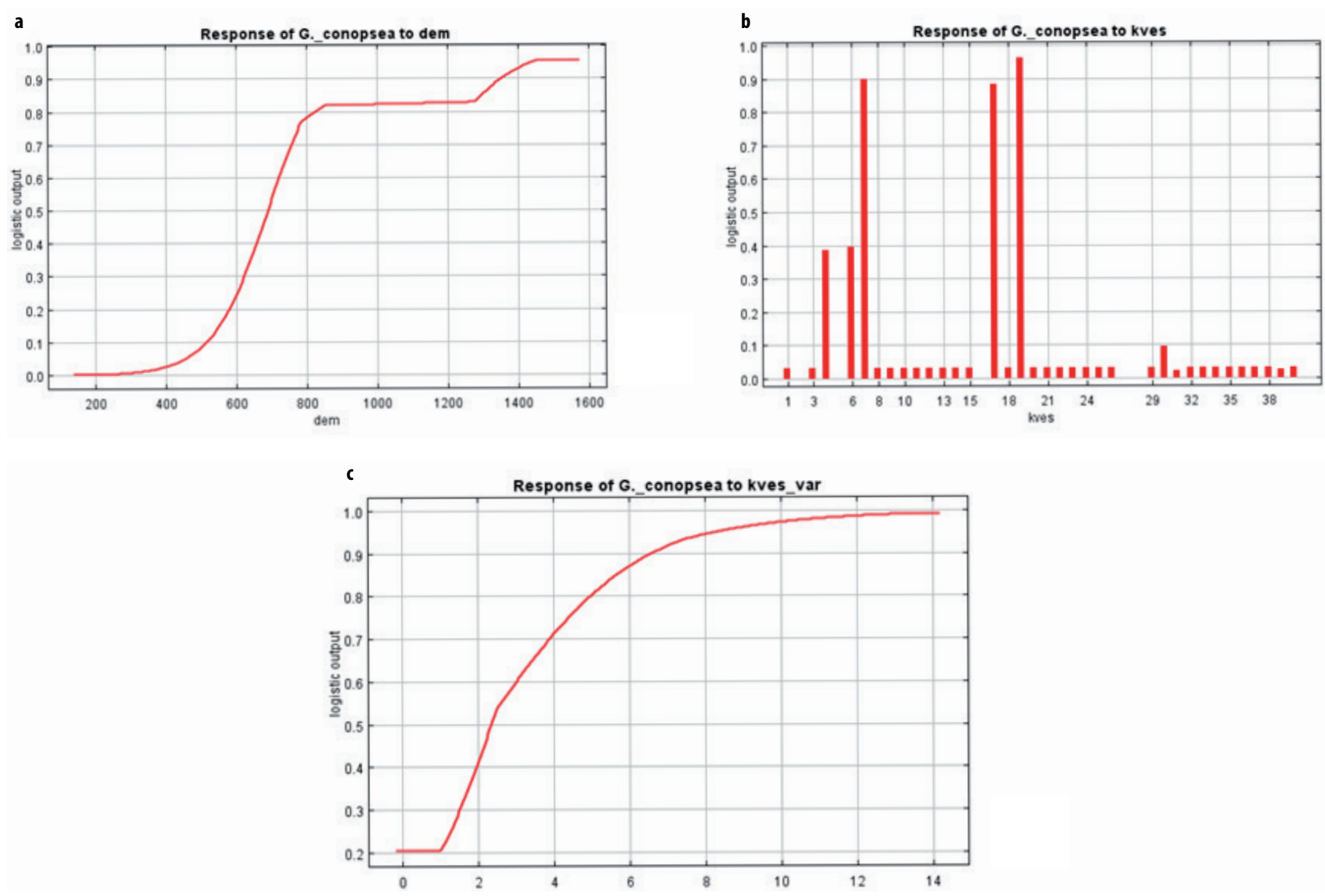

Fig. 9 Association of Gymnadenia conopsea with a) altitude (dem), b) consolidated layer of ecosystems (KVES) and c) habitat heterogeneity (KVES_var).

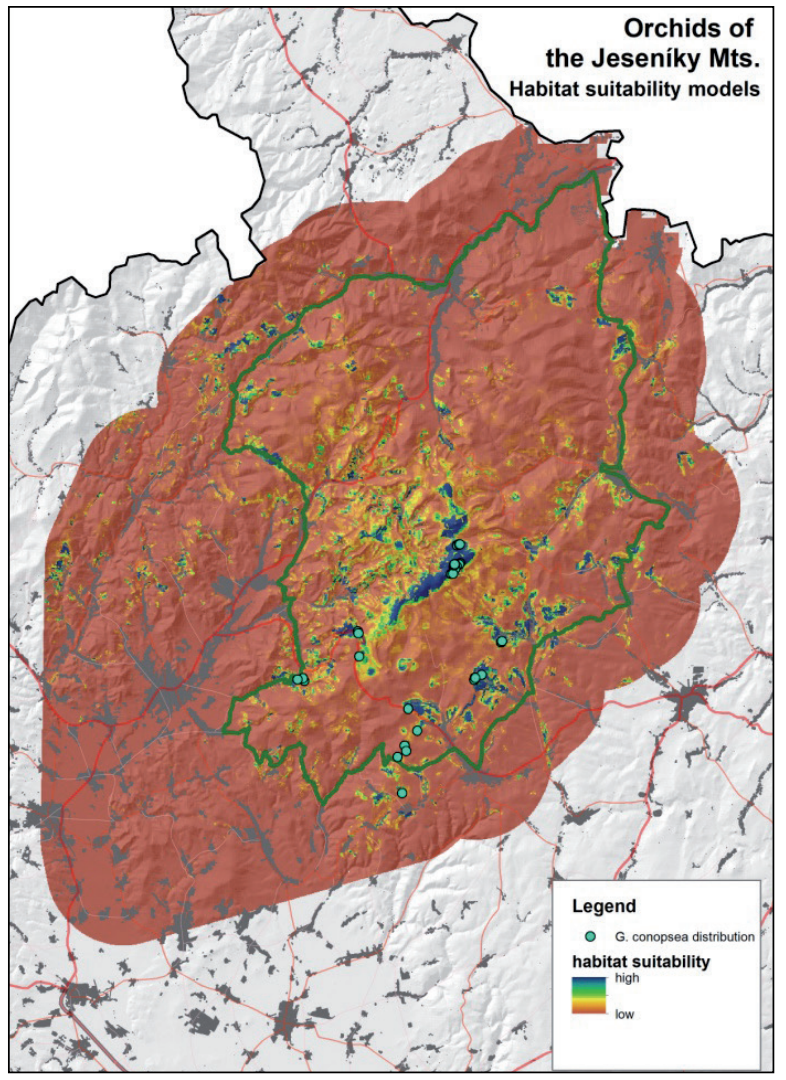

Fig. 10 Map showing the potential distribution of Gymnadenia conopsea in the Jeseníky Mountains. The green line indicates the borders of Jeseníky Nature Conservation Area

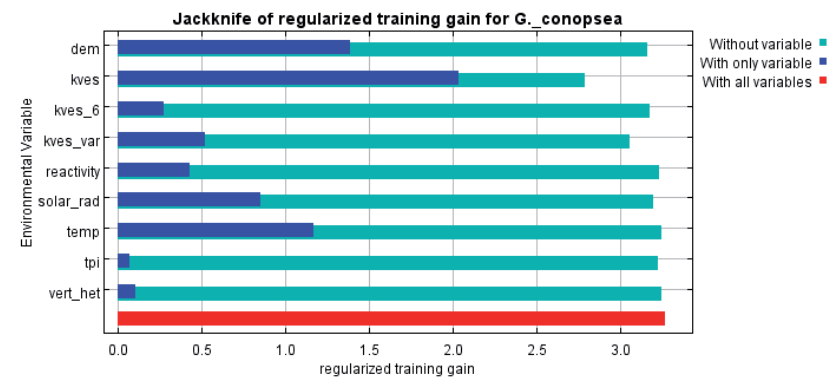

Fig. 11 The graph of the results of the jack knife procedure of selected factors for Platanthera bifolia.

places and tall grasses in mesophilic meadows also provide shade. Wet meadows can also include tall vegetation or border on forests. Our results are in accordance with the information in the literature (Procházka and Velísek 1983; Dykyjová 2003; Jersáková and Kindlmann 2004; Průša 2005), which indicate that this species occurs in forests as well as meadows, and also occurs in wet and dry places.

In Fig. 12c, the association between the distribution of P. bifolia and habitat heterogeneity (KVES_var) is displayed. Clearly, this species occurs mainly in areas of high environmental heterogeneity, that is, areas that consist of many small habitats. The probability of this species occurring in an area covered by a single habitat is almost zero. 

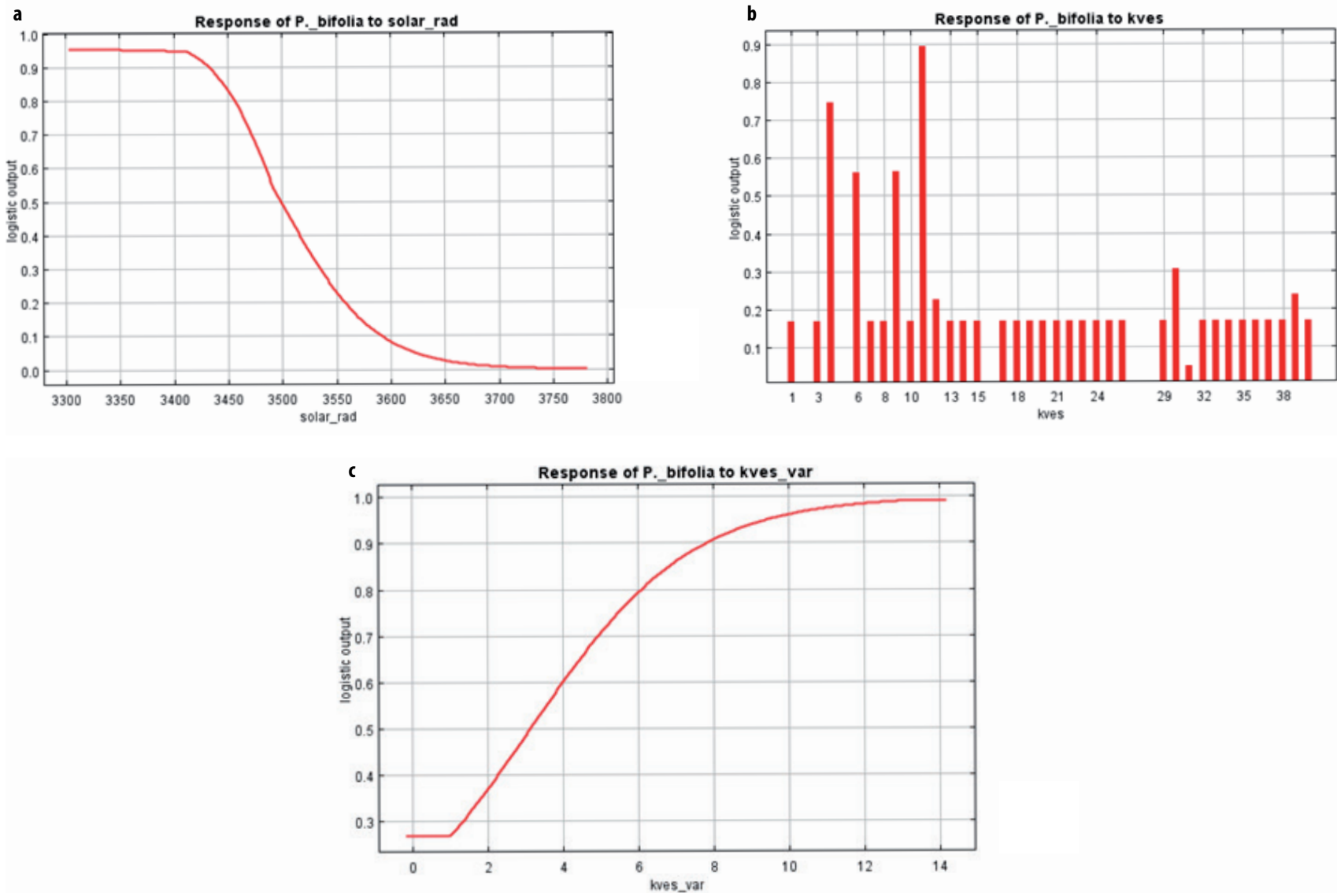

Fig. 12 Association of Platanthera bifolia with a) solar radiation (solar_rad), b) consolidated layer of ecosystems (KVES) and c) habitat heterogeneity (KVES_var).

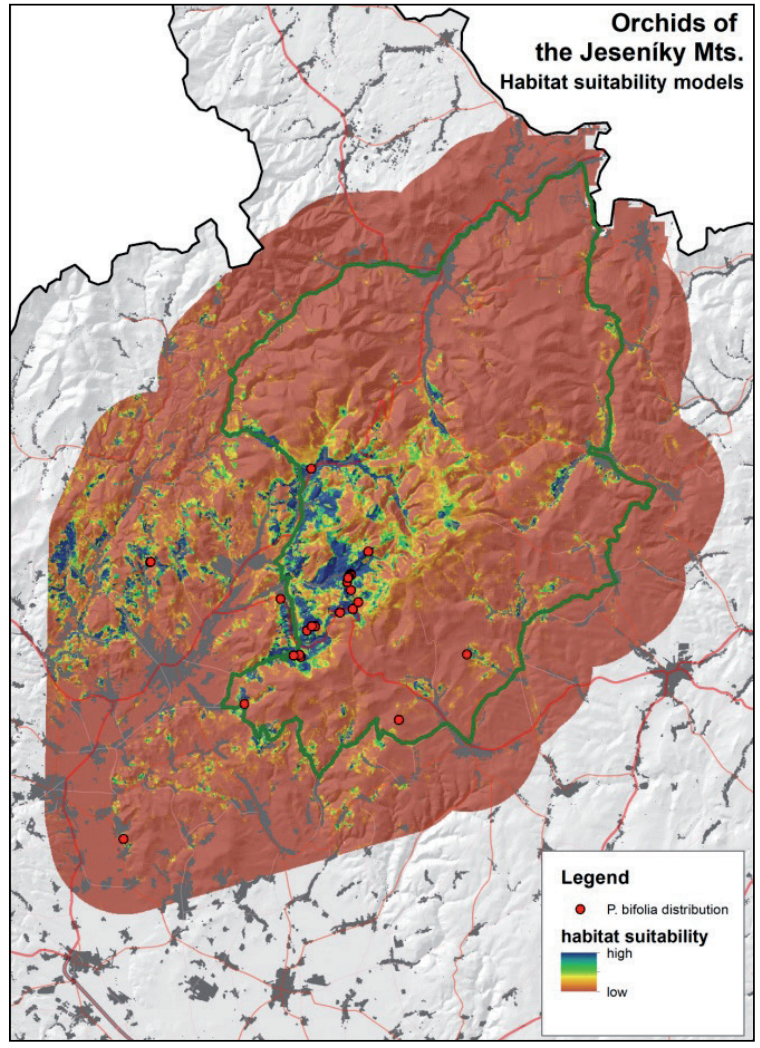

Fig. 13 Map showing the potential distribution of Platanthera bifolia in the Jeseníky Mountains. The green line is the border of the Jeseníky Nature Conservation Area.
Fig. 13 is a map showing the potential distribution of P. bifolia in the area studied. This map shows four other potential places that are suitable for the occurrence of this species: east of the village Sobotín around the stream Merta, around the village of Kouty nad Desnou, between the village of Loučná nad Desnou and the Dlouhé Stráně water reservoir, and around the village of Štědrákova in the east of the region studied.

\section{Conclusions}

The Maxent program is a useful tool for predicting the potential occurrence of endangered species in selected areas or a country, not only for orchids. Based on the results of this study, the most important factors for the species studied were different types of vegetation (consolidated layer of ecosystems; KVES) and high environmental heterogeneity and landscape structure (KVES_var). For the two species of Dactylorhiza studied, the common important factor was the nature of the bedrock (reactivity), or more precisely they mainly occur in areas with phyllite rocks and rarely in those with greywacke.

The results could be very helpful in identifying new, yet unknown localities of Dactylorhiza fuchsii, Dactylorhiza majalis, Gymnadenia conopsea and Platanthera bifolia, which are endangered species in the Czech Re- 
public. Without a potential distribution map, searching for new localities would be time consuming and less effective. Such maps would also be helpful for orchid conservation as it would enable conservationists to focus on areas where it is most likely that particular species of orchids are present.

In general, this work should serve as a tool for orchid conservation and for determining the most important factors associated with the distributions of orchids in the Czech Republic.

\section{Acknowledgements}

This work was supported by the Ministry of Education, Youth and Sports of CR within the National Sustainability Program I (NPU I), grant number LO1415.

\section{REFERENCES}

Angulo DF, Ruiz-Sanchez E, Sosa V (2012) Niche conservatism in the Mesoamerican seasonal trpical dry forest orchid Barkeria (Orchidaceae). Evol Ecol 26: 991-1010.

AOPK ČR (2013) Konsolidovaná vrstva ekosystémů (electronic geographical data). Praha. Agentura ochrany př́rody a krajiny ČR. Detailní mapa krajinného pokryvu v 41 definovaných tř́ídách na území ČR.

Chase MW, Cameron KM, Barrett RL, Freudenstein JV (2003) DNA data and Orchidaceae systematics: a new phylogenetic classification. In: Dixon KW, Kell SP, Barrett RL, Cribb PJ (eds) Orchid conservation. Natural History Publications, Kota Kinabalu, Borneo, pp 69-89.

Chuman T, Gürtlerová P, Hruška J, Adamová M (2014) Geochemical reactivity of rocks of the Czech Republic. J Maps 10: 341349.

Corsi F, Duprè E, Boitani L (1999) A large-scale model of wolf distribution in Italy for conservation planning. Conserv Biol 13: 150-159.

Cribb PJ, Kell SP, Dixon KW, Barrett RL (2003) Orchid conservation: a global perspective. In: Dixon KW, Kell SP, Barrett RL, Cribb PJ (eds) Orchid conservation. Natural History Publications, Kota Kinabalu, Borneo, pp 1-24.

Czech National Phytosociological Database. Vegetation Science Group, Department of Botany and Zoology, Faculty of Science, Masaryk University (2005). Web sites. http://www.sci.muni.cz /botany/vegsci/dbase.php?lang=cz. Accessed 21 February 2014.

Dirzo R, Raven PH (2003) Global state of biodiversity and loss. Annu Rev Env Resour 28: 137-167.

Dressler RL (1993) Phylogeny and classification of the orchid family. Cambridge University Press, Cambridge.

Dykyjová D (2003) Ekologie středoevropských orchidejí. Kopp, České Budějovice.

Efimov PG (2011) Revealing the decline and expansion of orchids of NW European Russia. Eur J Environ Sci 1: 7-17.

Elith J, Graham CH, Anderson RP, Dudík M, Ferrier S, Guisan A, Hijmans RJ, Huettmann F, Leathwick JR, Lehmann A, Li J, Lohmann LG, Loiselle BA, Manion G, Moritz C, Nakamura M, Nakazawa Y, Overton JM, Peterson AT, Phillips SJ, Richardson K, Scachetti-Pereira R, Schapire RE, Soberon J, Williams S, Wisz MS, Zimmermann NE (2006) Novel methods improve prediction of species' distributions from occurrence data. Ecography 29: 129-151.

Elith J, Leathwick JR (2009) Species distribution models: ecological explanation and prediction across space and time. Ann Rev Ecol Evol S 40: 677-697.

Elith J, Phillips SJ, Hastie T, Dudík M, Chee YE, Yates CJ (2011) A statistical explanation of MaxEnt for ecologists. Divers Distrib 17: 43-57.

Feldman D, Prat D (2011) Conservation recommendations from from a large survey of French orchids. Eur J Environ Sci 1: 8-27.

Ferrier S, Faith DP, Arponen A, Drielsma M (2009) Community-level approaches to spatial conservation prioritization. In: Moilanen A, Wilson AK, Possingham HP (eds) Spatial conservation prioritization. Quantitative methods and computational tools. Oxford University Press Inc., New York, pp 94-109.

Ferrier S, Guisan A (2006) Spatial modelling of biodiversity at the community level. J Appl Ecol 43: 393-404.

Fourcade Y, Engler JO, Rödder D, Secondi J (2014) Mapping species distributions with MAXENT using a geographically biased sample of presence data: a performance assessment of methods for correcting sampling bias. PLOS ONE 9: e97122.

Gelfand AE, Schmidt AM, Wu S, Silander JA, Latimer A, Rebelo AG (2005) Modelling species diversity through species level hierarchical modelling. Appl Statist 54: 1-20.

Guisan A, Thuiller W (2005) Predicting species distribution: offering more than simple habitat models. Ecol Lett 8: 993-1009.

Guisan A, Tingley R, Baumgartner JB, Naujokaitis-Lewis I, Sutcliffe PR, Tulloch AIT, Regan TJ, Brotons L, McDonald-Madden E, Mantyka-Pringle C, Martin TG, Rhodes JR, Maggini R, Setterfield SA, Elith J, Schwartz MW, Wintle BA, Broennimann O, Austin M, Ferrier S, Kearney MR, Possingham HP, Buckley YM (2013) Predicting species distributions for conservation decisions. Ecol Lett 16: 1424-1435.

Hernandez-Ruiz J, Herrera-Cabrera BE, Delgado-Alvarado A, Salazar-Rojas VM, Bustamante-Gonzales Á, Campos-Contreras JE, Ramírez-Juarez J (2016) Potential distribution and geographic characteristics of wild populations of Vanilla planifolia (Orchidaceae) Oaxaca, Mexico. Rev Biol Trop 64: 235-246.

Jersáková J, Kindlmann P (2004) Zásady péče o orchidejová stanoviště. Kopp, České Budějovice.

Kolanowska M (2013) Glacial refugia and migration routes of the Neotropical genus Trizeuxis (Orchidaceae). Acta Soc Bot Pol 82: 225-230.

Nature Conservation Agency of the Czech Republic (2006). Web sites. http://portal.nature.cz/publik_syst/ctihtmlpage.php?what =3\&nabidka=hlavni. Accessed 24 March 2014.

Peppler-Lisbach C, Schröder B (2004) Predicting the species composition of Nardus stricta communities by logistic regression modelling. J Veg Sci 15: 623-634.

Peterson AT, Shaw J (2003) Lutzomyia vectors for cutaneous leishmaniasis in southern Brasil: ecological niche models, predicted geographic distribution, and climate change effects. Int J Parasitol 33: 919-931.

Peterson AT, Soberón J, Sánchez-Cordero V (1999) Conservatism of ecological niches in evolutionary time. Science 285: 1265 1267.

Phillips SJ, Anderson RP, Schapire RE (2006) Maximum entropy modeling of species geographic distributions. Ecol Model 190: 231-259.

Phillips SJ, Dudík M (2008) Modeling of species distributions with Maxent: new extensions and a comprehensive evaluation. Ecography 31: 161-175.

Possingham HP, Wilson KA (2005) Turning up the heat on hotspots. Nature 436: 919-920. 
Procházka F, Velísek V (1983) Orchideje naší přírody. Academia, Praha.

Průša D (2005) Orchideje České republiky. Computer Press, Brno.

Reina-Rodríguez GA, Rubiano JE, Llanos FAC, Otero JT (2016) Spatial distribution of dry forest orchids in the Cauca River Valley and Dagua Canyon: towards a conservation strategy to climate change. J Nat Conserv 30: 32-43.

Scott JM, Heglund PJ, Morrison ML, Haufler JB, Raphael MG, Wall WA, Samson FB (2002) Predicting species occurrences: issues of accuracy and scale. Island Press, Washington, DC.

South Bohemian Branch. Czech Botanical Society (2017). Web sites. https://botanospol.cz/cs/node/42. Accessed 25 March 2014.

Tsiftsis S, Tsiripidis I, Trigas P (2011) Identifying important areas for orchid conservation in Crete. Eur J Environ Sci 1: 28-37.

Vogt-Schilb H, Munoz F, Richard F, Schatz B (2015) Recent declines and range changes of orchids in Western Europe (France, Belgium and Luxembourg). Biol Conserv 190: 133-141.
Vollering J, Schuiteman A, de Vogel E, van Vugt R, Raes N (2016) Phytogeography of New Guinean orchids: patterns of species richness and turnover. J Biogeogr 43: 204-214.

Wan J, Wang C, Han S, Yu J (2014) Planning the priority protected areas of endangered orchid species in northeastern China. Biodivers Conserv 23: 1395-1409.

Welk E, Schubert K, Hoffmann MH (2002) Present and potential distribution of invasive mustard (Alliara petiolata) in North America. Divers Distrib 8: 219-233.

Yom-Tov Y, Kadmon R (1998) Analysis of the distribution of insectivorous bats in Israel. Divers Distrib 4: 63-70.

Zhang Z, Yan Y, Tian Y, Li J, He J-S, Tang Z (2015) Distribution and conservation of orchid species richness in China. Biol Conserv 181: 64-72. 